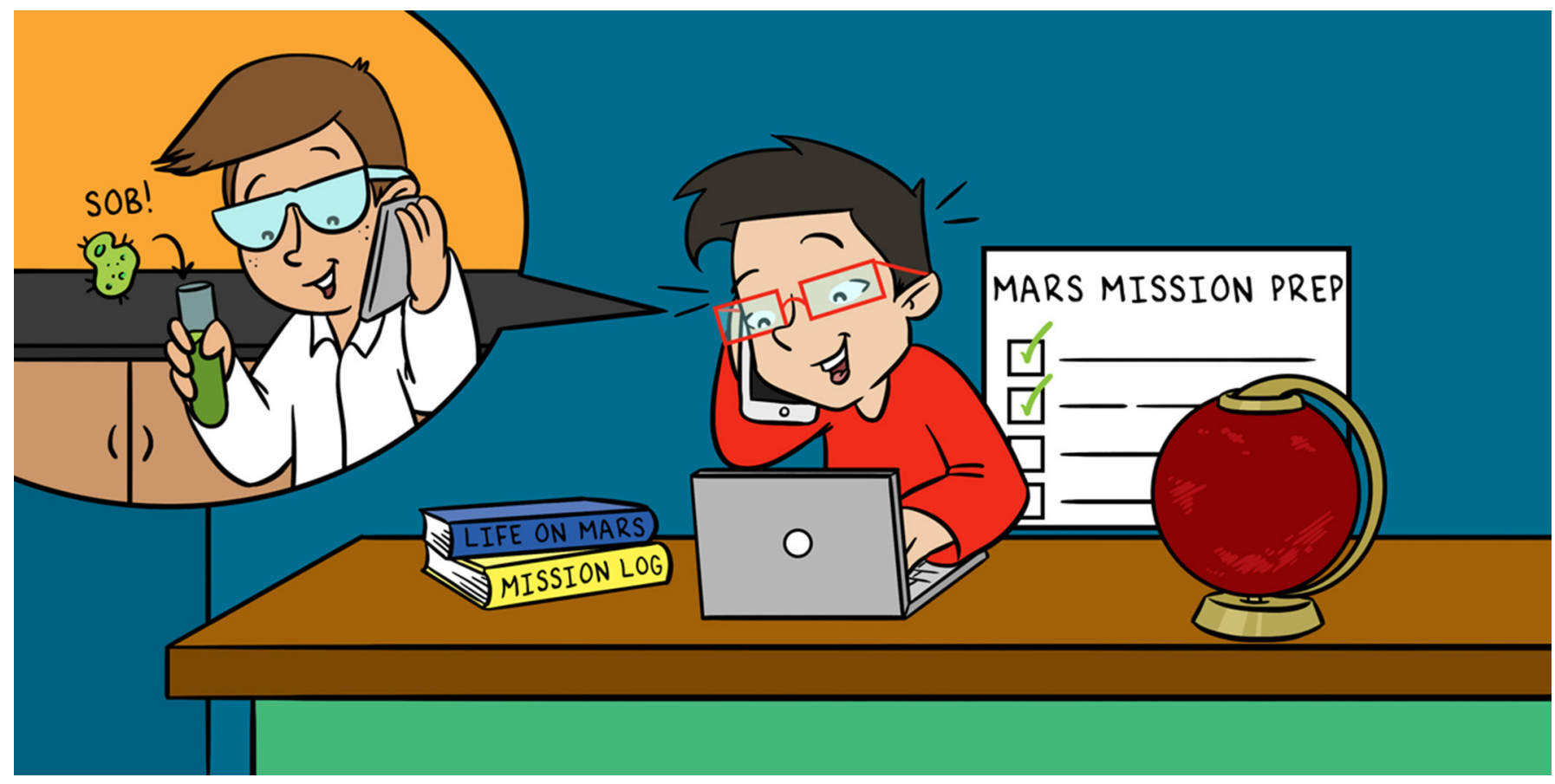

\title{
HUNTING FOR LIFE ON MARS BY STUDYING LIFE ON EARTH
}

Michael C. Macey ${ }^{1 *}$, Ann Grand ${ }^{1}$, Mark Fox-Powell ${ }^{1,2}$, Nisha K. Ramkissoon ${ }^{1}$, Claire R. Cousins ${ }^{2}$ and Karen Olsson-Francis ${ }^{1}$

${ }^{1}$ Faculty of Science, Technology, Engineering and Mathematics, AstrobiologyOU, The Open University, Milton Keynes, United Kingdom

${ }^{2}$ School of Earth and Environmental Sciences, University of St Andrews, St Andrews, United Kingdom

\section{YOUNG REVIEWERS:}

FAYDH

MOHAMMED

AGE: 15

GINNY

AGE: 12
Modern-day Mars is a dry, harsh environment with no surface water, but billions of years ago it might have been water-rich, like Earth. Scientists believe that, as water was lost on Mars, the remaining water would have become increasingly salty and rich in sulphur. By researching environments on Earth with a similar chemistry, we can develop hypotheses about whether life could have existed on Mars. In our research, we studied Colour Peak, a sulphur-rich, salty spring system in the Canadian High Arctic. This environment contains bacteria that use sulphur to get their energy. By studying water and sediment samples from this region, we confirmed that bacteria that used sulphur as an energy source could potentially have lived on Mars. These results can help scientists who are analysing data from Mars missions to identify evidence of former life on Mars. 


\section{CHONPS}

An acronym for carbon, hydrogen, oxygen, nitrogen, phosphorous, and sulphur. These are considered the key elements for life as they make up nearly $98 \%$ of all molecules in living cells.

\section{INDUCTIVELY}

COUPLED PLASMA OPTICAL EMISSION SPECTROSCOPY (ICP-OES)

A scientific technique that works by heating water to create plasma (a hot and energised gas) and detecting the colours of light given off by each element in the water.

\section{THE WATER OF MARS}

All living things need water. Since 1971, nine missions have successfully landed on Mars, and there are currently 14 satellites orbiting the planet. None of these missions have found any evidence of water or life on the surface today. However, those missions have observed structures (such as river basins) and water-bearing rocks and minerals (such as clays) on Mars' surface, which may be evidence for the presence of water [1]. Scientists believe that, billions of years ago, there was water on Mars.

Mars lost its water due to the partial loss of its atmosphere, but thanks to data from missions, scientists have an idea of the environment on early Mars. Scientists believe that, as the water started to evaporate, it became salty (at least twice as salty as Earth's seawater) and rich in sulphur, especially in the form of sulphide. This is the chemical that gives the smell to rotten eggs! We also know that the key elements required for life on Earth (carbon, hydrogen, nitrogen, oxygen, phosphorous and sulphur; abbreviated as CHNOPS) have all been identified in martian rocks and soils.

If life ever existed on Mars, it would have existed in or near bodies of water, and these potential martian organisms might have left behind evidence of their existence. Before we send missions to Mars to search for evidence of life, we need to have an idea of what kind of evidence we should look for. This preparation is important, because sending missions to Mars is incredibly complicated and expensive. Scientists start their preparation by studying environments on Earth that have similar water chemistries to that of early Mars. No environment on Earth is a perfect fit, but there are many that are similar enough for us to develop our understanding of martian water and whether life could have ever existed in it.

One such environment is the Colour Peak spring system on Axel Heiberg Island in the High Arctic of Canada (Figure 1), where the water is very salty and sulphur-rich. The average air temperature at Colour Peak is $-20^{\circ} \mathrm{C}$. In winter, it can go as low as $-40^{\circ} \mathrm{C}$, but the springs on the island never freeze because of their high salt content (in the same way that salt is spread on roads to stop ice from forming) $[2,3]$. We collected sediment and water samples from Colour Peak and stored them at a low temperature until they reached a laboratory in the United Kingdom.

We analysed the chemistry of the water from Colour Peak springs using a technique called inductively coupled plasma optical emission spectroscopy (ICP-OES). ICP-OES works by heating water to create plasma (a very hot, energised gas) and detecting the specific colours of light given off by each element in the water. Using geological data from the surface of Mars that was collected by the NASA Curiosity rover, we used a computer programme to model the chemical composition 
Figure 1

(A) Map of Axel Heiberg Island, with land shown in brown and icecaps shown in white. Colour Peak is marked by a star and two other salty springs are marked by red dots. (B)

Photograph of Colour Peak with labels showing the sources of its springs. The map was produced by modifying an image from Google Maps (Map Data @2020 Google) using the program Illustrator Creative Cloud version 21.0.2. These images are reproduced from Macey et al., [3] under creative commons licence 4.0 (creativecommons.org/ licenses/by/4.0/).

\section{$16 S$ rRNA GENE}

This gene plays a role in cell growth and replication. It is in all bacteria in a related form, and the differences in sequence can be used to identify bacteria.

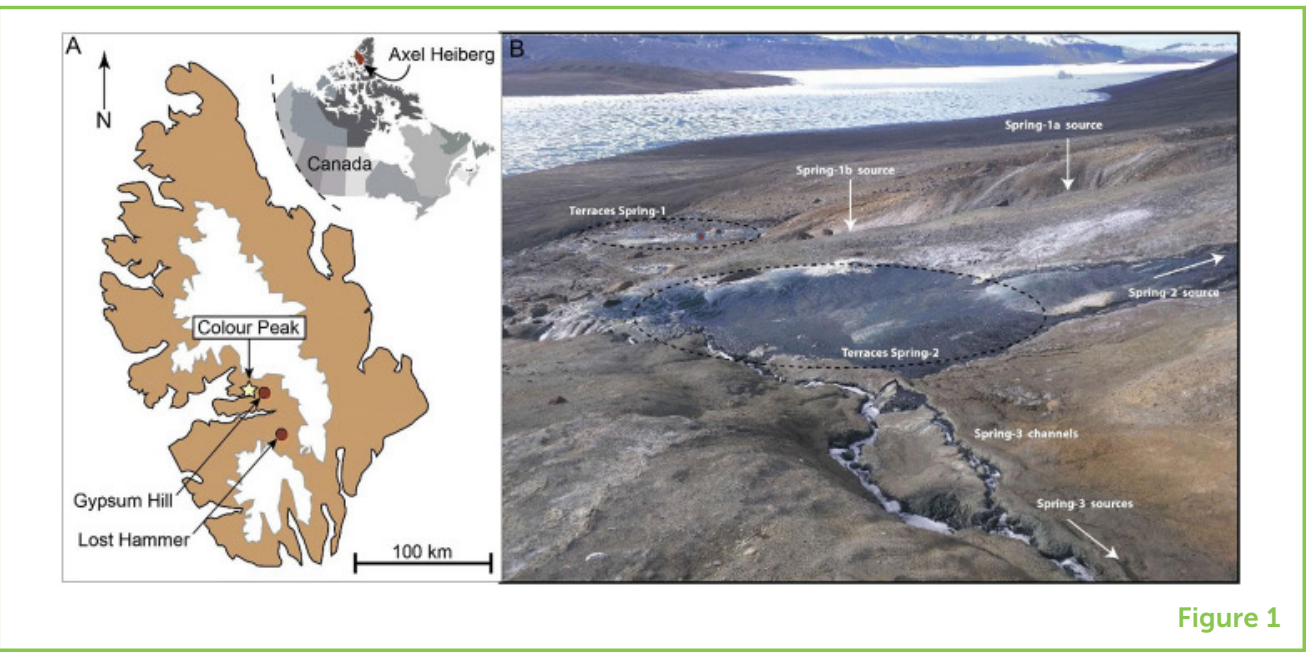

of the ancient water on Mars [4]. The composition of the predicted martian water was incredibly similar to the composition of the water from Colour Peak. This means the bacteria living in the Colour Peak springs are surviving and growing under conditions like those that might have once existed on Mars.

\section{WHAT LIVES IN COLOUR PEAK WATER?}

We identified the bacteria that live in the Colour Peak springs by looking at their deoxyribonucleic acid (DNA). The well-known double helix of DNA is the genetic code that instructs cells to produce many kinds of proteins and regulates how those proteins are used in cellular functions. There is one key gene that lets us identify the bacteria that live in an environment: the 16S rRNA gene. This gene, which exists in a related but slightly different form in all types of bacteria, performs a key role in bacterial replication and growth. By studying this gene in an environment, we can identify the various kinds of bacteria that live there.

However, before we could study the gene, we first had to extract (remove) the DNA from the bacteria in our samples. To do this, we had to overcome two major problems. First, the standard way to extract DNA from bacteria is to use chemicals to burst the cells open, leaving only the DNA behind. The high amounts of salt in the Colour Peak water caused some of these chemicals to react in strange ways, meaning that we could not collect any DNA. Second, because the Colour Peak water is cold and salty, the DNA from bacteria that died and burst thousands of years ago was preserved, and we cannot tell the DNA from long-dead bacteria apart from that of living bacteria [5].

To overcome the first problem, we washed the samples with ultrapure water to wash away the salt from the bacteria. To solve the second 
Figure 2

Proposed sources of the life-essential elements (carbon, nitrogen, oxygen, phosphorous and sulphur - CHNOPS) for the SOB within Colour Peak springs and the water environments predicted on Mars. The presence of the elements in the sediment and the concentrations of carbon dioxide and oxygen in the atmosphere are based on either studies of the environment of Colour Peak or data from missions to the surface of Mars [6, 7]. These images are reproduced from Macey et al., [3] under creative commons licence 4.0 (creativecommons.org/ licenses/by/4.0/)

\section{SULPHUR}

OXIDISING

BACTERIA

A type of bacteria that get energy from sulphur.

\section{AUTOTROPHY}

This is the process of making complex compounds (e.g., the building blocks that make up a cell) from simple substances (e.g. like

carbon dioxide $-\mathrm{CO}_{2}$ ).

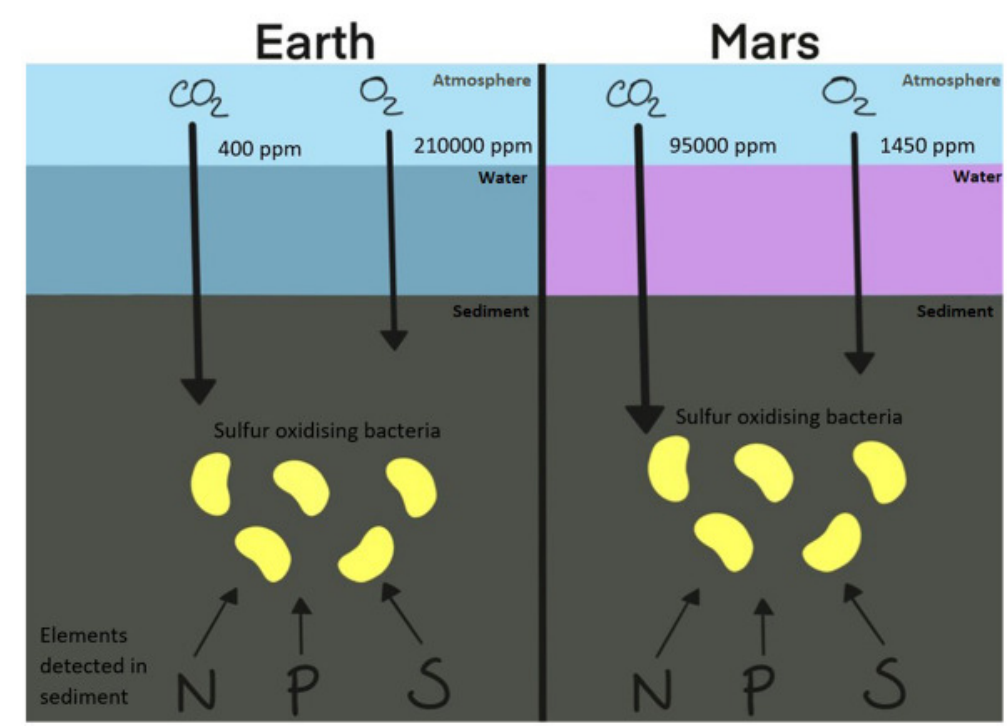

Figure 2

problem, we studied ribonucleic acid (RNA) as well as DNA. RNA is a single-stranded copy of the DNA that a cell reads to produce proteins. RNA breaks down incredibly quickly, even in cold and salt-rich conditions, so looking for the 16S rRNA gene in the RNA as well as in the DNA helped us to know which bacteria were alive when the samples were taken. Using this approach, our research revealed that most bacteria living in Colour Peak belong to a group called sulphur-oxidising bacteria (SOB) [3].

\section{WHAT DO THESE RESULTS MEAN FOR MARS?}

SOB use sulphur as a source of energy. Given the large amount of sulphur in Colour Peak water, it makes sense that this is a successful way to live in this environment. The water of ancient Mars would also have contained lots of sulphur, meaning that the main energy source for SOB would have been available. Many SOB obtain the carbon they need by capturing it from carbon dioxide in the air, like plants do-this is called autotrophy. Autotrophy would also be a good strategy on Mars, due to the large amount of carbon dioxide in the atmosphere [95,000 parts per million (ppm) compared to 415 ppm on Earth]. Some SOB can also grow without oxygen (which is very low on Mars), and can instead use nitrogen-based chemicals, called nitrates, which have been detected in the rocks of Mars (Figure 2) [6].

After showing that SOB can thrive in the Colour Peak water and knowing that all the key elements (CHNOPS) required for growth are present, we investigated whether the martian water we had modelled would actually support bacterial growth. This is important because, as well as needing specific elements, SOB would also need to produce enough energy to grow. If we know the concentrations of the specific 


\section{Figure 3}

The steps involved in this study. Fieldwork steps are in white, microbiology steps are in yellow, chemistry in orange, and the Mars-focused work in red.

\section{GIBBS ENERGY \\ EQUATION}

This is an equation that can be used to calculate how much energy a specific chemical reaction will produce.

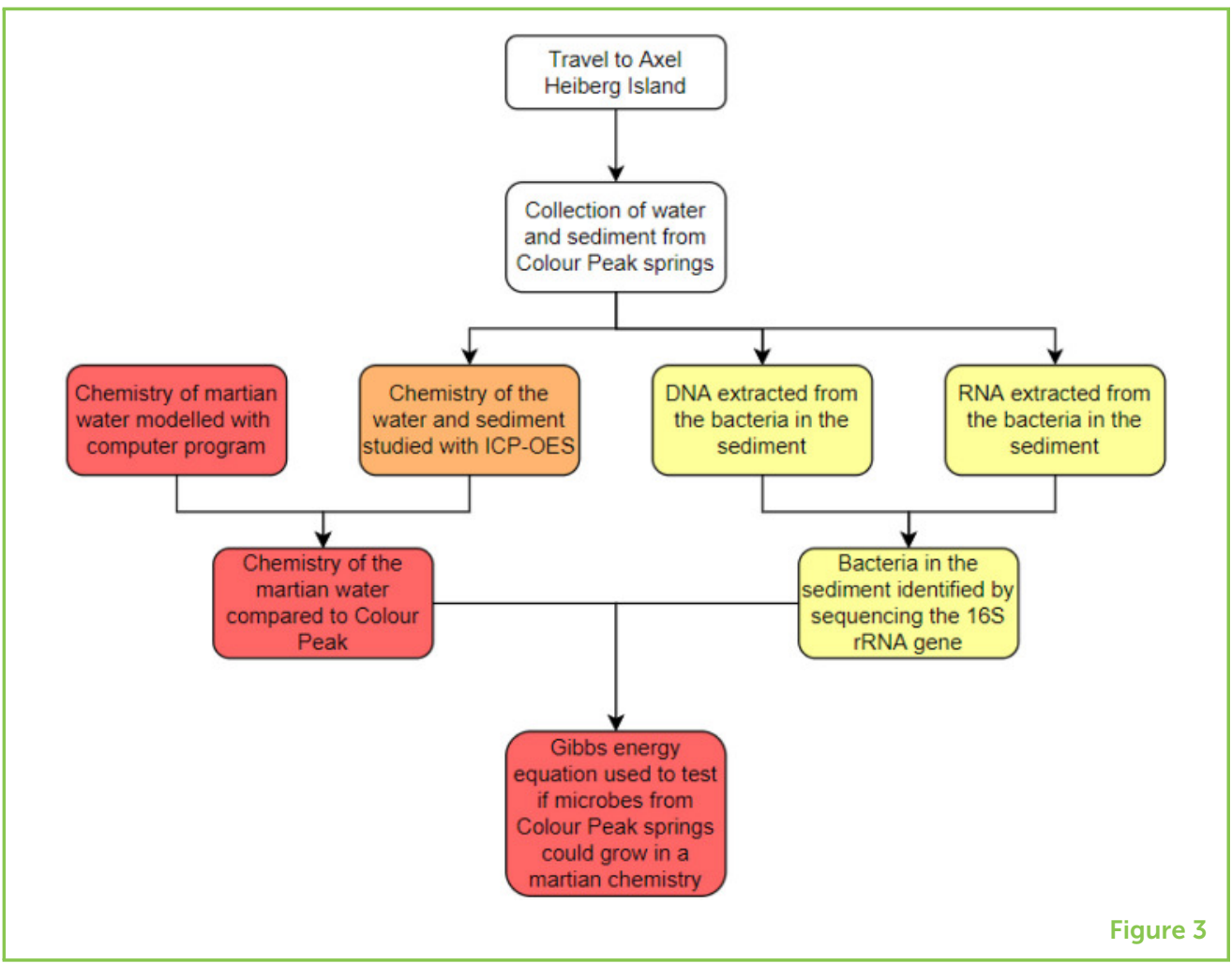

elements, we can calculate whether there is enough of these elements to produce the energy that the bacteria need. The equation used to calculate the energy is called the Gibbs energy equation and it was developed by the scientist Willard Gibbs [8]. Using the Gibbs energy equation, we can say that not only would SOB produce enough energy to grow, but they would also be one of the only types of bacteria that could grow in these specific waters. An outline of our work is shown in Figure 3.

This is a very exciting result, because SOB alter the chemistry of their local environment as they grow. This produces evidence of life, including the build-up and formation of specific chemicals and minerals, which can be used as evidence of life even long after the bacteria are dead $[9,10]$. If bacteria like SOB once grew on Mars, it is possible that the kind of evidence left behind by SOB on Earth could be found on Mars.

\section{THE FUTURE}

We have studied an environment on Earth (the salty, sulphur-rich waters of Colour Peak Springs) that is considered to be similar to environments on early Mars (4.1-3.7 billion years ago). From this work, we have been able to gain a better understanding of what kinds of life might have been able to survive on Mars. By combining microbiology, chemistry, and modelling, we showed that sulphur oxidising bacteria 
thrive in this Arctic spring water, and so potentially would have been able to grow on early Mars.

As we are writing this, two rovers (NASA's Perseverance and the Chinese Space Administration's Tianwen-1) have recently landed on Mars. Understanding the data that these missions obtain and determining if life did exist on Mars will take many years and will ultimately be completed by future generations of young researchers. We are excited to think that our work and methods will contribute to addressing one of the biggest questions of our time: Are we alone in the universe?

\section{ORIGINAL SOURCE}

Macey, M. C., Fox-Powell, M., Ramkissoon, N. K., Stephens, B. P., Barton, T., Schwenzer, S. P., et al. 2020. The identification of sulfide oxidation as a potential metabolism driving primary production on late noachian mars. Sci Rep. 10:10941. doi: 10.1038/s41598-020-67815-8

\section{REFERENCES}

1. Carr, M. H., and Head, J. W. 2010. Geologic history of Mars. Earth Planet Sci Lett. 294:185-203. doi: 10.1016/j.epsl.2009.06.042

2. Perreault, N. N., Andersen, D. T., Pollard, W. H., Greer, C. W., and Whyte, L. G. 2007. Characterization of the prokaryotic diversity in cold saline perennial springs of the Canadian high arctic. Appl Environ Microbiol. 73:1532-43. doi: 10.1128/AEM.01729-06

3. Macey, M. C., Fox-Powell, M., Ramkissoon, N. K., Stephens, B. P., Barton, T., Schwenzer, S. P., et al. 2020. The identification of sulfide oxidation as a potential metabolism driving primary production on late noachian mars. Sci Rep. 10:10941. doi: 10.1038/s41598-020-67815-8

4. Bridges, J. C., and Schwenzer, S. P. 2012. The nakhlite hydrothermal brine on Mars. Earth Planet Sci Lett. 359-60:117-23. doi: 10.1016/j.epsl.2012.09.044

5. Willerslev, E., Hansen, A. J., Rønn, R., Brand, T. B., Barnes, I., Wiuf, C., et al. 2004. Long-term persistence of bacterial DNA. Curr Biol. 14:13-4. doi: 10.1016/j.cub.2003.12.012

6. Stern, J. C., Sutter, B., Freissinet, C., Navarro-González, R., McKay, C. P., Archer, P. D., et al. 2015. Evidence for indigenous nitrogen in sedimentary and aeolian deposits from the Curiosity rover investigations at Gale crater, Mars. Proc Natl Acad Sci USA. 112:4245-50. doi: 10.1073/pnas.1420932112

7. Mahaffy, P. R., Webster, C. R., Atreya, S. K., Franz, H., Wong, M., Conrad, P. G., et al. 2013. Abundance and isotopic compoisition of gases in the Martian atmosphere from the Curiosity rover. Science. 341:263-6. doi: 10.1126/science.1237966 
8. McCollom, T. M. 2007. Geochemical constraints on sources of metabolic energy for chemolithoautotrophy in ultramafic-hosted deep-sea hydrothermal systems. Astrobiology. 7:933-50. doi: 10.1089/ast.2006.0119

9. Battler, M. M., Osinski, G. R., and Banerjee, N. R. 2013. Mineralogy of saline perennial cold springs on axel Heiberg Island, Nunavut, Canada and implications for spring deposits on Mars. Icarus. 224:364-81. doi: 10.1016/j.icarus.2012.08.031

10. Pellerin, A., Antler, G., Holm, S. A., Findlay, A. J., Crockford, P. W., Turchyn, A. V., et al. 2019. Large sulfur isotope fractionation by bacterial sulfide oxidation. Sci Adv. 5:eaaw1480. doi: 10.1126/sciadv.aaw1480

SUBMITTED: 08 February 2021; ACCEPTED: 23 September 2021; PUBLISHED ONLINE: 18 October 2021.

EDITED BY: Edward Gomez, Las Cumbres Observatory Global Telescope Network, United States

CITATION: Macey MC, Grand A, Fox-Powell M, Ramkissoon NK, Cousins CR and Olsson-Francis K (2021) Hunting for Life on Mars by Studying Life on Earth. Front. Young Minds 9:665529. doi: 10.3389/frym.2021.665529

CONFLICT OF INTEREST: The authors declare that the research was conducted in the absence of any commercial or financial relationships that could be construed as a potential conflict of interest.

COPYRIGHT (c) 2021 Macey, Grand, Fox-Powell, Ramkissoon, Cousins and Olsson-Francis. This is an open-access article distributed under the terms of the Creative Commons Attribution License (CC BY). The use, distribution or reproduction in other forums is permitted, provided the original author(s) and the copyright owner(s) are credited and that the original publication in this journal is cited, in accordance with accepted academic practice. No use, distribution or reproduction is permitted which does not comply with these terms.
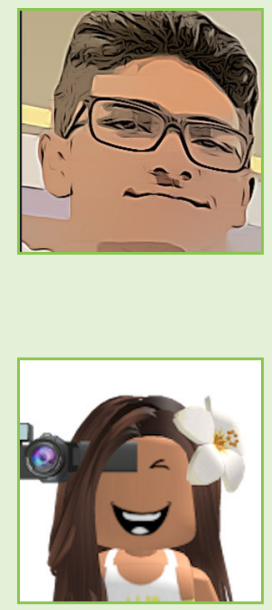

\section{YOUNG REVIEWERS}

\section{FAYDH MOHAMMED, AGE: 15}

My name is Faydh Mohammed. I like to play a lot of different sport and to learn interesting things. I am keen on technology and I like exploring new tech tools and gadgets. I am a somewhat artistic drawer too. I want to develop my mind and talents to pursue a fulfilling course for my senior years. I am very excited to be working with Frontiers for Young Minds!

\section{GINNY, AGE: 12}

Ever since I was a little girl, I grew up in the world of science and I found my love for math and computers. I decided to work as a Reviewer as it would give me the opportunity to learn how scientific papers are published. I love to read and be with my friends. I am so excited to see what adventures are in store for me in the future. 


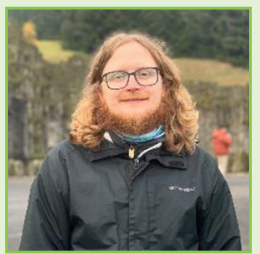

\section{AUTHORS}

\section{MICHAEL C. MACEY}

Michael is a microbiologist working in AstrobiologyOU, investigating bacteria that can survive in extreme environments on Earth and testing if these bacteria can grow under martian conditions. Previously, Michael investigated plant-associated bacteria and their impact on the atmosphere. During his undergraduate studies, he completed an Erasmus year, during which he researched the gut bacteria of earthworms, and in his final year of his undergraduate degree he worked with viruses that infect soil bacteria. Michael is a champion for the Microbiology Society and the book that got him interested in pursuing microbiology is Microcosm by Carl Zimmer. *michael.macey@open.ac.uk
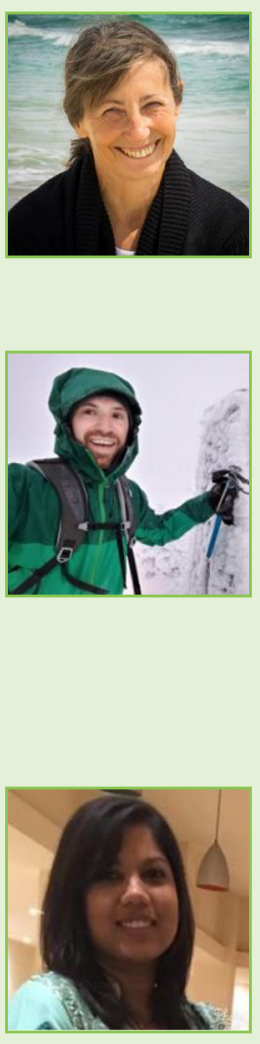

\section{ANN GRAND}

Ann is lecturer in astrobiology education, working to integrate the research carried out by AstrobiologyOU into resources for formal and informal education. Her research covers several areas of science communication and public engagement, but she focusses on open research and how researchers use digital media and tools to engage with members of the public about their research.

\section{MARK FOX-POWELL}

Mark is a research fellow with the AstrobiologyOU group at The Open University. He studies brines (naturally salty water), which can stay liquid at sub-zero temperatures and could act as habitats for life across the solar system, including on Mars and in the icy shells of worlds like Europa, a moon of Jupiter. His work involves lab experiments, computer modelling, and occasionally fieldwork to Arctic locations like the Colour Peak springs. He studied marine biology at University in Plymouth and is fascinated by areas of science in which traditional fields, like chemistry and biology, overlap.

\section{NISHA K. RAMKISSOON}

Nisha is a planetary scientist currently working in AstrobiologyOU at The Open University. She combines computer models and laboratory experiments to investigate whether microbial life could grow on Mars or in the ocean of Jupiter's satellite, Europa, and what biosignatures they could leave behind. Prior to this, she explored how meteorite impacts on Mars could affect the evolution of the planet's crust and atmosphere.

\section{CLAIRE R. COUSINS}

Claire is a senior lecturer in the School of Earth and Environmental Sciences at the University of St Andrews, where she conducts research in the fields of planetary science and astrobiology. Claire investigates volcanic environments and the life residing within them and uses Mars-like terrains in Iceland to scientifically develop the PanCam instrument on the 2022 ESA Rosalind Franklin rover. 


\section{KAREN OLSSON-FRANCIS}

Karen is a professor of geomicrobiology and Director of Astrobiology at The Open University. She is interested in microorganisms that survive in extreme environments. She developed an interest in extremophiles during her gap year in New Zealand and studied extremophiles for her Ph.D. at the University of Otago in New Zealand. This led to 2 years of studying microorganisms in cow stomachs (to try to stop methane production), before returning to the UK to start a career in astrobiology. Karen is Chair of the UK Geomicrobiology Network and a member of the European Astrobiology Institute and European Astrobiology Network Association committees. 